\title{
PROPOSAL AND VERIFICATION OF PROJECT MANAGEMENT METHODS AND TOOLS ORIENTED MATURITY MODEL
}

\begin{abstract}
Project management maturity greatly influences the success rate of the project implementation. However, available project management maturity models (PMMMs) are costly, time-consuming and demanding in terms of organization and competence when it comes to application. Moreover, there is no PMMM that evaluates in detail the usage of recommended project management methods and tools. The goal of this article is to design a user-friendly PMMM that would evaluate the project management maturity based on assessment of the usage of project management tools and methods within each stage of project life cycle taking into account the predominant type of projects implemented. The authors used the critical and comparative analysis, based on that the available project management maturity models were assessed and the new PMMM was designed using analogy, deduction, and induction, based on the synthesis of the acquired knowledge combined with the expert experience of the practitioners. It is a unique PMMM, characterized by complexity, user friendliness and financial flexibility. In addition, it is a model that can be used not only in companies of various branches, but also in organizations of other institutional sectors.
\end{abstract}

Keywords: Project Management. Project Management Maturity Models. Project Management Methods and Tools. Type of Projects. Project Life Cycle.

\section{PROPOSTA E VERIFICAÇÃO DE MÉTODOS DE GESTÃO DE PROJETOS E FERRAMENTAS ORIENTADA A UM MODELO DE MATURIDADE}

\section{RESUMO}

A maturidade em gestão de projetos influencia muito o nível de sucesso da implementação de projetos. Entretanto, os modelos de maturidade em gestão de projetos (PMMMs) disponíveis são caros, demorados e exigem muito esforço e competências da organização quando são aplicados. Além disso, não há nenhum PMMMs que avalie em detalhe o uso dos métodos e ferramentas recomendados em gestão de projetos. O objetivo deste artigo é projetar um PMMM amigável que avaliará a maturidade em gestão de projetos baseados na avaliação do uso das ferramentas e métodos em cada estágio do ciclo de vida do projeto, considerando o tipo de projeto predominante que está sendo implementado. Os autores aplicaram análise crítica e comparativa, baseada nos modelos de maturidade disponíveis, e um novo PMMM foi projetado, usando analogia, dedução e indução, com base na síntese do conhecimento adquirido combinado com a experiência de praticantes. É um PMMM único, caracterizado pela complexidade, facilidade de uso e flexibilidade financeira. Além de que é um modelo que pode ser usado em organizações com várias filiais, mas também com atuação em vários setores.

Palavras-chave: Gestão de Projeto. Modelos de Maturidade em Gestão de Projetos. Métodos e Ferramentas em Gestão de Projetos. Tipo de Projetos. Ciclo de Vida de Projetos.

\footnotetext{
${ }^{1} \mathrm{PhD}$ at the Faculty of Chemical Technology, University of Pardubice, Pardubice, Czech Republic. Assistant professor (Lecturer in Management) at the Faculty of Chemical Technology, University of Pardubice, Pardubice, Czech Republic. Email: jana.kostalova@upce.cz

${ }^{2} \mathrm{PhD}$ at the Faculty of Chemical Technology, University of Pardubice, Pardubice, Czech Republic. Associate professor (Lecturer in Business and Management) at the Faculty of Chemical Technology, University of Pardubice, Pardubice, Czech Republic. E-mail: libena.tetrevova@upce.cz
} 


\section{INTRODUCTION}

In the present continuously changing environment of the economic world, any business entity can only enjoy prosperity and future existence on condition that it is able to implement changes quickly, effectively, and in a suitable manner. Changes are usually made in the form of projects where project management is used for managing them. By applying project management, companies can make a number of changes in all the areas of the corporate activity, i.e. in the areas of manufacturing, marketing, sales, organization, information, but also in the areas of finance, personnel or innovation.

The success rate in implementing projects is very closely related to project management maturity and to the use of appropriate project management methods and tools. The positive influence of using these methods and tools on the success and efficiency of projects has been confirmed by a number of studies, such as those by Patanakul et al. (2010) or Lappe and Spang (2014). Meredith and Mantel (2012) also note that increasing the organization competencies in project management is a key factor for improving the project management processes. In order to develop competencies or improve processes in project management, we first need to evaluate project management maturity and identify the baseline and weaknesses, on which it is appropriate to focus in increasing the competencies and improving the processes.

The research question is how to evaluate project management maturity at the enterprise level. To assess it, we can use a number of models. Generally, these models are called Project Management Maturity Models (PMMMs). Backlund et al. (2014) define PMMM as a tool with the intention to evaluate project maturity level and to identify improvement areas. Kerzner (2001) states that maturity models are considered to be strategic tools used by senior managers to identify areas for improvement and to prioritize improvement actions. International standards IPMA, PMI, PRINCE 2, other available methodologies and professional literature recommend not only appropriate procedures or competences, but also suitable project management methods and tools for implementing project management in practice. Based on these standards, methodologies, and research studies, a number of PMMMs have been created. If it is possible to evaluate project management maturity based on the assessment of the use of procedures, it is possible and efficient to derive project management maturity from the extent of use of project management methods and tools.

This article aims to identify and compare available PMMMs and then, based on this comparison and the expertise of practitioners, suggest a suitable way to evaluate project maturity level in the organization, on the basis of which we could obtain information about project management maturity level and identify suitable areas for improvement. The goal of the article is to design a user-friendly PMMM that would evaluate the project management maturity based on the assessment of usage of project management tools and methods within each stage of the project life cycle taking into account the predominant type of projects implemented.

\section{LITERATURE REVIEW}

The project management theory has been addressing the issue of project management maturity evaluation on a long-term basis (Albrecht \& Spang, 2014). Prado (2011) and Souza \& Gomez (2015) state that project management maturity is the position, in which the organization finds itself regarding the project management processes. Based on this, maturity models seek to quantify the ability of the organization to manage projects successfully. These are the purposes the PMMMs have been designed for.

Historically, evaluation of project management maturity is based on models used to evaluate management in a wider range. An example is the Capability Maturity Model (CMM) developed by Software Engineering Institute (SEI) at Carnegie Mellon University in the USA in 1986 to evaluate management maturity in systems and software engineering (Souza \& Gomez, 2011; CMMI Institute, 2016). Later, in 2002, this model was extended to the Capability Maturity Model Integration (CMMI) (Wendler, 2012; Tahri \& Drissi-Kaitouni, 2015; CMMI Institute, 2016). The first PMMMs in the form of Excellence Model were also inspired by the concept of quality management based on the European Foundation for Quality Management (EFQM) (Bushuyev \& Wagner, 2014; Hertogh et al., 2008).

The existence of many maturity models and PMMMs is illustrated in the literature. In the literature, the existence of more than 40 PMMMs is presented (Chang \& Wei, 2014; Yang \& Qiu, 2010). Grant \& Pennypacker (2006) mention the existence of 30 PMMMs, Spalek (2015) reports the existence of 32 PMMMs, Kwak et al. (2015) report the existence of 27 maturity models, including PMMMs. Albrecht \& Spang (2016) analyze 15 selected PMMMs. However, the authors also often include available Process Management Maturity Models in these figures (e.g. CMM or CMMI) or Project Management Office Maturity Models or other modifications of maturity models. On the basis of 
professional literature, the authors of the paper managed to identify 43 PMMMs. At the same time, they identified 16 models that are classified as PMMMs in some cases but assess a broader or different area than the project management (i.e. risk management, human resource management, software development).

As regards the comparison of PMMMs, there are various classification aspects available. PMMMs may be process-oriented and organizationoriented (Spalek, 2015). In case the PMMMs focus on evaluation of capability or competencies in project management, they are called competenceoriented models (Backlund et al., 2014). PMMMs focus on the evaluation of project management maturity on the level of management of projects, programs or project portfolios. They can be based on international project management standards, or on simpler methodologies, individual or group research. An overview of the 29 core PMMMs identified is given in Table 1.

Table 1 - Project Management Maturity Models

\begin{tabular}{|c|c|c|c|c|c|}
\hline No. & Name & Acronym & $\begin{array}{c}\text { Theoretical } \\
\text { base }\end{array}$ & $\begin{array}{c}\text { Author of the } \\
\text { PMMM/References }\end{array}$ & Type of PMMMs \\
\hline 1 & PRINCE 2 Maturity Model & P2MM & PRINCE 2 & Axelos, 2013 & process-oriented \\
\hline 2 & $\begin{array}{l}\text { Portfolio Management Maturity } \\
\text { Model }\end{array}$ & P3M3 & PRINCE 2 & Axelos, 2010 & process-oriented \\
\hline 3 & $\begin{array}{l}\text { P2CMM Project Management } \\
\text { Maturity Model }\end{array}$ & P2CMM & PRINCE 2 & Lianying et al., 2012 & process-oriented \\
\hline 4 & $\begin{array}{c}\text { Project Management Maturity } \\
\text { Model }\end{array}$ & PMMM & PMI & Fincher \& Levin, 1997 & process-oriented \\
\hline 5 & $\begin{array}{c}\text { Project Management } \\
\text { Assessment } 2000 \\
\end{array}$ & $\begin{array}{l}\text { PMA } 2000 \\
\text { Model }\end{array}$ & PMI & Lubianiker, 2000 & $\begin{array}{l}\text { organization and } \\
\text { process-oriented }\end{array}$ \\
\hline 6 & $\begin{array}{c}\text { Organizational Project } \\
\text { Management Maturity Model }\end{array}$ & OPM3 & PMI & $\begin{array}{l}\text { Project Management } \\
\text { Institute, } 2001\end{array}$ & $\begin{array}{l}\text { organization and } \\
\text { process-oriented }\end{array}$ \\
\hline 7 & $\begin{array}{l}\text { Project Management Process } \\
\text { Maturity }\end{array}$ & $\mathrm{PM}^{2}$ & PMI & Kwak \& Ibbs, 2002 & process-oriented \\
\hline 8 & $\begin{array}{l}\text { Kerzner Project Management } \\
\text { Maturity Model }\end{array}$ & KPM3 & PMI & Kerzner, 2014, 2001 & $\begin{array}{c}\text { process-oriented } \\
\text { (competence-oriented) }\end{array}$ \\
\hline 9 & $\begin{array}{l}\text { Project Management Solution } \\
\text { Project Management Maturity } \\
\text { Model }\end{array}$ & $\mathrm{PMMM}^{\mathrm{SM}}$ & PMI & $\begin{array}{l}\text { Crawford, 2015; PM } \\
\quad \text { Solution, } 2013\end{array}$ & process-oriented \\
\hline 10 & $\begin{array}{c}\text { ESI's Project Management } \\
\text { Maturity Model - Project } \\
\text { FRAMEWORK }\end{array}$ & N/A & PMI & ESI International, 2016 & $\begin{array}{l}\text { organization and } \\
\text { process-oriented }\end{array}$ \\
\hline 11 & IPMA Delta Standard & $\begin{array}{l}\text { IPMA } \\
\text { Delta }\end{array}$ & IPMA & $\begin{array}{c}\text { International Project } \\
\text { Management } \\
\text { Association, } 2016 \\
\end{array}$ & organization-oriented \\
\hline 12 & Project Maturity Model & N/A & $*$ & Levene et al., 1995 & process-oriented \\
\hline 13 & $\begin{array}{c}\text { Project Management Maturity } \\
\text { Model by Micro-Frame } \\
\text { Technologies of Ontario, } \\
\text { California } \\
\end{array}$ & $\mathrm{PM}^{3}$ & $*$ & Remy, 1997 & process-oriented \\
\hline 14 & $\begin{array}{l}\text { Project Management Maturity } \\
\text { Model }\end{array}$ & PMMM & $*$ & Jain, 1998 & process-oriented \\
\hline 15 & $\begin{array}{l}\text { Educational Service Institute's } \\
\text { Project Management Maturity } \\
\text { Model }\end{array}$ & PMMM & $*$ & Ward, 1998 & process-oriented \\
\hline 16 & $\begin{array}{l}\text { Project Management Capability } \\
\text { Maturity Model }\end{array}$ & PMCMM & * & Voivedich \& Jones, 2001 & process-oriented \\
\hline
\end{tabular}




\begin{tabular}{|c|c|c|c|c|c|}
\hline 17 & $\begin{array}{l}\text { Project Management Maturity } \\
\text { Model }\end{array}$ & ProMMM & $*$ & Hillson, 2001, 2003 & process-oriented \\
\hline 18 & $\begin{array}{l}\text { Prado Project Management } \\
\text { Maturity Model }\end{array}$ & $\begin{array}{l}\text { Prado- } \\
\text { PMMM; } \\
\text { P2M3 } \\
\text { model }\end{array}$ & $\begin{array}{l}\text { PMI, IPMA, } \\
\text { PRINCE } 2\end{array}$ & Prado, 2002 & $\begin{array}{c}\text { organization and } \\
\text { process-oriented } \\
\text { (competence-oriented) }\end{array}$ \\
\hline 19 & $\begin{array}{l}\text { Andersen and Jenssen Project } \\
\text { Management Maturity Model }\end{array}$ & N/A & * & $\begin{array}{l}\text { Andersen \& Jenssen, } \\
2003\end{array}$ & $\begin{array}{l}\text { organization-oriented } \\
\text { (competence-oriented) }\end{array}$ \\
\hline 20 & $\begin{array}{l}\text { Project, Program Maturity } \\
\text { Model for a Project-oriented } \\
\text { Organization }\end{array}$ & $\begin{array}{l}\text { Cobweb } \\
\text { Model }\end{array}$ & $*$ & Fuessinger, 2006 & process-oriented \\
\hline 21 & $\begin{array}{c}\text { IBM Project Management } \\
\text { Center of Excellence Maturity } \\
\text { Model }\end{array}$ & WWPMM & $*$ & Harrington, 2006 & process-oriented \\
\hline 22 & $\begin{array}{l}\text { Model Maturity Increments in } \\
\text { Controlled Environments } 2\end{array}$ & MINCE 2 & $*$ & Meisner, 2007 & $\begin{array}{l}\text { organization-oriented } \\
\text { (competence-oriented) }\end{array}$ \\
\hline 23 & $\begin{array}{c}\text { Five Step and Maturity Level } \\
\text { Model by Project Institute } \\
\text { Finland }\end{array}$ & N/A & $*$ & $\begin{array}{l}\text { Project Institute Finland, } \\
\text { Haukka, } 2013\end{array}$ & $\begin{array}{l}\text { organization and } \\
\text { process-oriented }\end{array}$ \\
\hline 24 & $\begin{array}{l}\text { Outcomes and Learning-based } \\
\text { Maturity Model }\end{array}$ & OLMM & $*$ & Killen \& Hunt, 2013 & $\begin{array}{l}\text { organization and } \\
\text { process-oriented }\end{array}$ \\
\hline 25 & $\begin{array}{c}\text { Business Management } \\
\text { Consultants - BMC Project } \\
\text { Management Maturity Model }\end{array}$ & $\begin{array}{l}\text { PMMM- } \\
\text { BMC }\end{array}$ & $*$ & Farrokh, 2013 & $\begin{array}{c}\text { organization and } \\
\text { process-oriented } \\
\text { (competence-oriented) }\end{array}$ \\
\hline 26 & $\begin{array}{l}\text { Gartner's Program and Portfolio } \\
\text { Management Maturity Model }\end{array}$ & $\begin{array}{l}\text { Gartner's } \\
\text { PPM } \\
\text { Model }\end{array}$ & $*$ & Gartner Inc., 2014 & $\begin{array}{l}\text { organization and } \\
\text { process-oriented }\end{array}$ \\
\hline 27 & $\begin{array}{l}\text { PM: Road Map Maturity } \\
\text { Assessment }\end{array}$ & N/A & $*$ & $\begin{array}{l}\text { Interthink Consulting, } \\
2016\end{array}$ & $\begin{array}{l}\text { organization and } \\
\text { process-oriented }\end{array}$ \\
\hline 28 & Project Maturity Roadmap & N/A & $*$ & Pcubed, 2016 & organization-oriented \\
\hline 29 & $\begin{array}{c}\text { Portfolio Management Maturity } \\
\text { Model }\end{array}$ & ELENA & $*$ & Nikkhoua et al., 2016 & $\begin{array}{l}\text { organization and } \\
\text { process-oriented }\end{array}$ \\
\hline
\end{tabular}

Legend: *The author of the PMMM does not indicate any links to a specific international standard of project management.

Source: Authors

In addition to the generally usable PMMMs, we can also encounter PMMMs specialized in a particular area or scope of project management. Their overview is given in Table 2. 
Table 2 - Specialized Project Management Maturity Models

\begin{tabular}{|c|c|c|c|c|c|}
\hline No. & Name & Acronym & $\begin{array}{c}\text { Theoretical } \\
\text { base }\end{array}$ & $\begin{array}{c}\text { Author of the PMMM/ } \\
\text { References }\end{array}$ & Type of PMMMs \\
\hline 1 & $\begin{array}{c}\text { Construction Project } \\
\text { Management Maturity Model }\end{array}$ & CPM3 & $*$ & $\begin{array}{l}\text { Fengyong \& Renhui, } \\
2007\end{array}$ & $\begin{array}{l}\text { oriented towards } \\
\text { construction projects }\end{array}$ \\
\hline 2 & $\begin{array}{l}\text { Evolutionary Software Project } \\
\text { Management Maturity Model }\end{array}$ & $\mathrm{ESPM}^{3}$ & $*$ & Sukhoo et al., 2007 & $\begin{array}{l}\text { oriented towards } \\
\text { software projects }\end{array}$ \\
\hline 3 & Infra Maturity Tool & IMT & $\begin{array}{l}\text { PRINCE } 2 \text { a } \\
\text { EFQM } \\
\text { Excellence } \\
\text { Model } \\
\end{array}$ & Hertogh et al., 2008 & $\begin{array}{l}\text { oriented towards large } \\
\text { infrastructure projects }\end{array}$ \\
\hline 4 & Project Risk Maturity Model & PRMM & $*$ & Hopkinson, 2010 & $\begin{array}{l}\text { oriented towards } \\
\text { assessment of capability } \\
\text { in project risk } \\
\text { management }\end{array}$ \\
\hline 5 & $\begin{array}{l}\text { Agile-SW-an Agile Project } \\
\text { Management Maturity Model } \\
\text { for Software Organizations }\end{array}$ & AP3M-SW & PMI & Soares \& Meira, 2014 & $\begin{array}{c}\text { oriented towards } \\
\text { software development } \\
\text { process-oriented }\end{array}$ \\
\hline 6 & $\begin{array}{l}\text { Conceptual Model for Assessing } \\
\text { Project Management Maturity }\end{array}$ & N/A & $*$ & Spalek, 2015 & $\begin{array}{l}\text { oriented towards } \\
\text { industrial companies }\end{array}$ \\
\hline 7 & $\begin{array}{l}\text { Prosci's Change Management } \\
\text { Maturity Model TM }\end{array}$ & N/A & $*$ & Prosci, 2004 & $\begin{array}{c}\text { oriented towards change } \\
\text { management }\end{array}$ \\
\hline 8 & $\begin{array}{l}\text { Project Management System } \\
\text { Maturity Model }\end{array}$ & N/A & $*$ & Vandersluis, 2017 & $\begin{array}{l}\text { oriented towards usage } \\
\text { of project management } \\
\text { information systems }\end{array}$ \\
\hline
\end{tabular}

Legend: *The author of the PMMM does not indicate any links to a specific international standard of project management.

Source: Authors

An alternative approach to project management maturity assessment is designed by Pasian (2014), who does not evaluate the project management maturity based on processes or competence, but focuses on the non-process factors influencing project management capability/maturity.

Used by PwC to assess project management maturity in blanket screenings (PwC, 2014), the PwC's Project Management Maturity Assessment can also be presented as PMMM. Project Excellence Model by Westerveld (2002) and PM3 model by Markensteijn (2001) are primary usable as project management methodologies, but they can also be used also for the evaluation of project management maturity as PMMMs.

Another approach to creating PMMMs is based on the evaluation of project management maturity in the context of the specific conditions of the national environment. Examples of PMMMs based on this approach include the Reference Model for Project Management Certification in Czech Organizations designed in the Czech branch of IPMA (Adamek et al., 2013) or the Hrazdilova Bockova Model respecting the specific conditions of project management in the Czech Republic (Hrazdilova Bockova, 2009).

The project management maturity models represent qualitative evaluation models. They are generally based on a uniform approach where areas of project management are first defined by, for example, using project management standards. They are then used to assess the level at which the processes are carried out in the area and the extent to which the shape of the processes is standardized and implemented at the same level repeatedly. They are also used to examine the link to the organization's strategy. Alternatively, necessary capabilities or competencies of project managers to manage relevant areas can be defined.

Therefore, in these models, it is project management processes or competencies of project managers that are primary for the project management maturity assessment rather than the application of various project management methods and tools. An approach focusing on the evaluation of processes is based on the historical context where the first PMMMs were created based on the Capability Maturity Models and also on the concepts of quality 
management and Excellence Model. An approach based on the competencies of project managers is then applied in models using the IPMA standard and works with the concept of this standard.

It should also be noted that the models P2MM, P3M3, P2CMM, OPM3, KPM3, PM², $\mathrm{PMMM}^{\mathrm{SM}}$, Open Maturity Model and IPMA Delta Standard are closely linked with the respective international project management standards and largely evaluate and assess the extent to which the standard is applied in practice. Also, the fact is that these models evaluate project management maturity in great detail, so they are administratively demanding and time-consuming.

The PMMMs usually evaluate the project management, or project, program and project portfolio management maturity differently, but in most cases they do not reflect e.g. what types of projects are dealt with in practice and whether, in the light of this fact, the processes applied are adequate. Suitability of the processes with regard to the project type is taken into account only with the Project Excellence Model (Westerveld, 2002) and Five Step and Maturity Level Model (Haukka, 2013). Also, models specialized in a certain area (see Table 2) can be considered PMMMs that take the project type in account. The models OPM3 and CPM3 are also exceptions that distinguish the application of the relevant processes in individual project life cycle (PLC) stages.

Regarding the aspect of the project management methods and tools, while the Spalek model (2015) also includes the use of project management methods and tools in the areas for the assessment of project management maturity, it does not specify what kind of methods and tools these are and just collectively assesses the extent of their use. Likewise, the Open Maturity Model (Lubianiker, 2000) evaluates the use of tools and techniques within individual processes according to the recommendations within the PMI standard.

Mullaly (2014) then has a critical view of the existing PMMMs, stating that in most cases PMMMs do not take the type of project into account when assessing the project management maturity. Neither is this view taken into account in the evaluation of processes and practices. The third area he criticizes with some existing PMMMs is the failure to consider the organizational and contextual factors, i.e. project environment.

Models presented in the literature are thus not primarily focused on the evaluation of project management maturity based on the assessment of the use of project management methods and tools and in most cases they do not take into account the predominant type of the projects implemented.

\section{METHODOLOGY}

The presented study is based on a literature review. Its subject was the analysis of secondary data - papers, books, conference papers, and specialized materials of relevant institutions. These were both publications in the area of management, especially project management, and mathematical modelling. The choice of literature sources was influenced by the importance and currency of the given source.

The secondary data analysis was followed by a qualitative research. This research was conducted from June 2014 to March 2015. In its framework, primary data was gathered through personal interviews and the focus group. Respondents of personal interviews were representatives of selected chemical companies responsible for project management. The companies were selected primarily on the basis of the membership of the Association of Chemical Industry of the Czech Republic and secondarily from the database of beneficiaries of European funds published on January 3, 2014 by the Ministry of Regional Development of the Czech Republic. Companies from the Association of Chemical Industry of the Czech Republic were identified that carry out projects co-financed from European funds. Representatives of 23 companies were approached, yet data were eventually provided by representatives of eight companies. Specifically, they were project managers (in six cases), a research director (in one case) and a company director (in one case). The specifications of the companies whose representatives participated in the research are shown in Table 3 . With regard to the anonymity requirement, individual businesses are further marked by letters A through $\mathrm{H}$. 
Table 3 - Basic Data about the Monitored Companies

\begin{tabular}{|c|c|c|c|c|c|}
\hline Company & Legal form & $\begin{array}{c}\text { Corporate } \\
\text { stock }\end{array}$ & $\begin{array}{c}\text { Number of } \\
\text { employees* }\end{array}$ & $\begin{array}{c}\text { Prevailing type } \\
\text { of projects }\end{array}$ & $\begin{array}{c}\text { No. of } \\
\text { applications/projects** }\end{array}$ \\
\hline A & cooperative & CZK30m & 70 & medium & $3 / 3$ \\
\hline B & joint-stock company & CZK1.027bn & 1000 & large & $10 / 9$ \\
\hline C & joint-stock company & CZK1.6bn & 350 & large & $8 / 7$ \\
\hline D & joint-stock company & CZK155m & 1200 & large & $5 / 3$ \\
\hline E & joint-stock company & CZK1bn & 600 & large & $6 / 4$ \\
\hline F & joint-stock company & CZK260m & 1600 & large & $9 / 3$ \\
\hline G & $\begin{array}{c}\text { limited liability } \\
\text { company }\end{array}$ & CZK5m & 570 & medium & $4 / 3$ \\
\hline H & joint-stock company & CZK103m & 220 & large & $6 / 6$ \\
\hline
\end{tabular}

Legend: *No. of employees rounded to whole tens ** No. of applications for support from European funds or No. of solved projects co-financed by

European Funds in programming period 2007 - 2014

Source: Authors

The structured interviews contained both open and semi-closed questions as well as closed questions. The structured interviews were conducted in two rounds, with an average duration of each interview being 2 hours. As part of the first round of interviews, the representatives of the companies discussed alternative options for evaluating the project management maturity, their priorities and constraints, and requirements were specified for their improvement.

Subsequently, the authors of the paper created a draft concept of their own project management maturity model. It was piloted on a sample of two companies and the results of the focus group with the project managers of these companies, representatives of Project Management Association (IPMA-CZ) and academics specializing in project management that contributed to its finalization. Based on the testing of the model concept and focus group, a model design was refined and finalized to the final form, which is described in Chapter 4.

Subsequently, the proposed model was verified. The data for its verification was obtained in the second round of interviews with representatives of the aforementioned eight companies. The second round of interviews also provided the final evaluation of the study.

When designing the model, from the procedural point of view, we used the classic procedure applied in the change process management. . From the merit point of view, knowledge gained from the literature review, interviews and focus group was used. At the same time, the practical experience of the authors of the model in the management of projects co-financed from European funds was used. In the process, standard research methods were applied in the form of critical and comparative analysis, synthesis and deduction.

\section{PREREQUISITES FOR DESIGNING AND DESIGNING OF PM2TOM2}

Based on the assessment of the available PMMMs and the structured interviews (see Chapter 3 ), there was a need to design a simple model that would allow the project maturity management in enterprises to be evaluated by themselves without the need to hire external consultants or specialized certification agencies, resources.

Before designing the Project Management Methods and Tools Oriented Maturity Model (PM2TOM2), it was first necessary to define the prerequisites on which the proposed model would be based. It was necessary to choose an appropriate division of PLC, define the types of projects, the predominant type of which is to be taken into account in the evaluation in the assessed organization, select appropriate project management methods and tools, evaluate their use in individual PLC stages and define organizational and software support to the project management on the organizational level.

\subsection{Prerequisites for Designing of PM2TOM2}

\subsubsection{Project Life Cycle}

The project can be divided into several stages, the sequence of which is called the PLC. These are uniquely denotable units that are characterized by the achievement of measurable and 
verifiable output of the project (Project Management Institute, 2004).

Standard PRINCE 2 (Association for Project Management, 2012) divides the PLC into four stages: 1st - the concept, 2nd - definition, 3rd implementation, 4th - handover and closeout. Standard PMI (Project Management Institute, 2004) divides the PLC into three stages: initial, intermediate and final. Maylor (2010) identifies four stages of the PLC, namely the definition of the project, design of the project process, delivery of the project and development of the process. Oellgaard (2013) divides the PLC into six stages, namely the scope, analysis, design, building, implementation and operation.

In our opinion, the division of the PLC into these stages can be considered optimal: concept, planning, implementation and evaluation. Concept is a stage where the project intent is defined and assessed and the project objective is defined. Planning is a stage where detailed partial plans are drawn up. Implementation is a stage where the project is implemented on the basis of the detailed partial plans and evaluation is a stage where the project is completed and evaluated, and the project outputs are, as the case may be, utilized (Kostalova \& Tetrevova, 2016).

\subsubsection{Division of Projects}

Projects can be divided in many ways. Projects can be divided from the point of view of the volume of the project budget (Archibald, 2013; Youker, 2017), from the point of view of the project complexity (Archibald, 2013; Vidal et al., 2011), from the point of view of time (Youker, 2017; Crawford et al., 2004), from the point of view of the nature of the project outputs (Archibald, 2013; Youker, 2017; Besner \& Hobbs, 2012; Rosenau, 2009), from the point of view of the rate of the project risk (Archibald, 2013), from the point of view of the position of the project in relation to the project solver (Fiala, 2008) or from the territorial point of view (Gareis, 2005). We could also divide projects from the point of view of the sector or branch of business in which the projects are implemented (Archibald, 2013), or from the point of view of the way of financing (Tetrevova, 2006). The problems of project typology are more closely dealt with by, for example, Archibald (2013), Youker (2017) or Turner \& Cochrane (1993).

The points of view taking account of the volume of the project budget, the time-demanding nature and complexity of the project seem to be the key points of view in relation to the character of the project. To design the model for evaluating project management maturity, the authors chose to divide projects into small projects that can be characterized as projects with a smaller budget, less time- demanding, with a low rate of complexity in planning and implementation of the project outputs. Then, they distinguish medium projects that can be characterized as projects with a larger budget, more time-demanding, ensuring creation of a more robust project output with a more complex planning and implementation. The last group of projects within this division comprises large projects that can be characterized as extensive projects with a large budget, time-demanding, whose aim is to ensure creation of an extensive output through application of complex procedures during planning and mainly during implementation. (Turner \& Ledwith, 2009)

Project differentiation based on this classification is relative and always dependent on a particular situation. The budget volume has to be considered within the context of the implementing organization, e.g. with respect to the annual turnover of the company, the annual balance sheet total, or the volume of the registered capital.

\subsubsection{Project Management Methods and Tools Suitable for Individual PLC Stages}

The theory of project management offers a variety of methods and tools for project management support. Procedures, methods and tools suitable to be applied are defined for individual PLC stages. In the concept stage, to design and evaluate the project proposal, we can use Feasibility Study (Haponava \& Al-Jibouri, 2009), the SWOT Analysis (Poster \& Applegarth, 2006; Robbins \& Coulter, 2004), methods for assessing the effectiveness of investment projects with financial benefits e.g. in the form of Net Present Value (NPV) (Mian, 2011) or methods for assessing the effectiveness of investment projects with non-financial benefits e.g. in the form of Cost Benefit Analysis (CBA) (Campbell \& Brown, 2003). Methods and tools suitable for specifying the project objectives include SMART Method (Maylor, 2010) or Logical Framework (Couillard et al., 2009).

In the project planning stage, to specify the exact scope of the project and its time course, we can use the Product Breakdown Structure (PBS) (Association for Project Management, 2012), Work Breakdown Structure (WBS) (Norman et al., 2008; Project Management Institute, 2004), Resource Breakdown Structure (RBS) (Rad \& Cioffi, 2004) and Risk Breakdown Structure (RiBS) (Project Management Institute, 2004). It is also possible to apply network analysis methods (Critical Path Method - CPM, Metra Potential Method - MPM, Critical Path Method/Cost - CPM/Cost, Program Evaluation and Review Technique - PERT, Graphical Evaluation and Review Technique GERT) (Hillier \& Lieberman, 2005; Ravindran, 2007), Gantt Chart (Project Management Institute, 2004), and Critical Chain Method (Goldratt, 1997). 
For source planning, it is also possible to make use of Resource Leveling (Rad \& Cioffi, 2004), Responsibility Assignment Matrix (Melnic \& Puiu, 2011), and Stakeholders Analysis (Project Management Institute, 2004). It is possible to use risk management methods and tools in the form of Risk Register (Project Management Institute, 2004), Ishikawa Diagram (Project Management Institute, 2004), Determination of the Expected Value of the Risk (Dolezal et al., 2012), or Decision Tree Analysis (Fiala, 2008). To draw up the project time schedule, but also to plan the risks, it is possible to apply Monte Carlo Method (Project Management Institute, 2004; Association for Project Management, 2012). For more details see e.g. (Kostalova \& Tetrevova, 2016).

In the stage of implementation of the project, it is important to monitor the progress of the project implementation. Using Earned Value Management (EVM) (Solanki, 2009; Storms, 2008), Structured Status Deviation (SSD) (Lee-Kwang \& Favrel, 1988), Milestone Trend Analysis (MTA) (Lester, 2007) and Project Percent Complete Method (Maylor 2010), we can track the progress of the project. As part of cost management, we can also use monitoring of costs in comparison with the budget (Meredith \& Mantel, 2012) and monitoring of the course of the project cash flow in comparison with its plan (Maravas \& Pantouvakis, 2012). With the end of the project, it is important to evaluate the project, e.g. using Lessons Learned (Carrilo et al., 2013; Jugdev, 2012).

In addition to methods and tools specific for individual stages of the PLC, we can also specify methods and tools applicable in all stages of the PLC. These are primarily methods and tools affecting organizational aspects of project management in the form of Organizational Standards to Support Project Management (Joslin \& Müller, 2015; Zandhuis \& Stellingwerf, 2013) and Project Management Office (PMO) (Project Management Institute, 2004; Unger et al., 2012; Müller et al., 2013). A specific approach to project management throughout the PLC is then represented by Agile Methods (Beck, 2001; Koerner, 2005).

\subsubsection{Organizational and Software Support}

The project management maturity is significantly affected by organizational support to projects and staff training - project environment (Shi, 2011). An important form of increasing the project management maturity level is also the use of external consultants and project managers for project management. Project management and the scope of its use are also reflected in the organizational structure. In the case of small projects, it is generally recommended to use project management only within individual organizational units. Middle and large projects should be managed in a matrix (or within the framework of a project-oriented) organizational structure, i.e. with the involvement of project team members from different organizational units (Dolezal et al., 2012). The highest maturity level is observed in project management in a projectoriented organizational structure, where the structure is geared to implementing projects and the basic organizational elements are not individual organizational units, but the currently implemented projects (Kwak et al., 2015).

It is also the use of software support that increases project management maturity (Ali et al., 2008). Generally, systems to support project management are known as Project Management Information System (PMIS). Current trends in the development and use of PMIS in practice lead from single-project management to integrated multiproject planning with the use of shared resources (Braglia \& Frosolini, 2012). In addition to project management support in individual stages of PLC, an important functionality of most PMIS is project documentation management, sharing of documents with the project team and other stakeholders (Meredith \& Mantel, 2012; Braglia \& Frosolini, 2012) and support in a multi-project environment (Ahlemann, 2009; Kaiser \& Ahlemann, 2010). To support project management methods and tools, to document projects especially in a multi-project environment, we can use various kinds of software tools, from simple cloud or freeware applications through software support using specialized applications with a wide range of functionality to complex software project management support (Kostalova et al., 2015).

\subsection{Designing of PM2TOM2}

Similarly to the existing PMMMs, the proposed PM2TOM2 evaluates project management maturity in defined areas. The determination thereof was based on the international standards of project management. 7 integrated areas were chosen for evaluation: time management, resource management, cost management, risk management, scope management, organizational support of the project, including staff training and project management software support based on literature review and the findings that emerged from the structured interviews with the practitioners. These areas were chosen so as to cover partial project management areas and take account of facts connected with the organizational support of the project, staff training in project management and the use of software support.

Maturity level evaluation criteria are defined for each area. For the area of management of time, resources, costs, risk and scope of the project, chosen as the criteria were project management 
methods and tools recommended for the management of the relevant areas by the project management theory (see Chapter 4.2). For the area of the organizational support to the project, including staff training, we chose criteria taking into account the approach of the assessed organization to staff training, the use of external consultants and project managers, the organization of project management and the use of project management tools in the form of Organizational Standards to Support Project Management and PMO, which can contribute to a more efficient form of project management. For the area of project management software support, we chose criteria assessing the software application utilized by the project manager to support project management.

Each criterion was assigned a point value, and in the evaluation the fulfilment of each criterion in practice in the monitored organization is assessed. The total of the point value for the use of each criterion was set with regard to the complexity of processing various methods, tools, or other criteria. The total of the point value of each criterion takes into account the stages of the PLC in which the different criteria are used. The highest score is assigned to the stage of the PLC where the method or tool of project management or any other criterion is supposed to be applied primarily. If a PLC stage does not affect the suitability of the use of a project management method or tool or other criterion, the points are distributed evenly.

For project management methods and tools and other criteria that provide similar benefits to project management maturity, we chose summary score for multiple items (e.g. in the field of time management, CPM and MPM are in a similar position; in terms of efficiency of activities in the project management, it is not desirable to process both CPM and MPM, and thus for obtaining the maximum score, it is sufficient if the assessed organization uses one of these methods). Given that all project management methods and tools and other criteria are not equally suitable for various types of projects, the final score is adjusted by coefficients reflecting the suitability of the criterion with respect to the prevailing type of the projects carried out. For example, in the event that there is a majority of small projects in the organization, it is not efficient to support them with complex software applications and it is sufficient to use freeware applications or cloud solutions. It is therefore assessed to what extent the criterion is suitable for the type of projects. The scoring thus reflects the complexity and demands of the individual project management methods and tools and other criteria, and the appropriateness of their use with regard to individual stages of PLC and the prevailing type of the projects carried out.
Annex A details the PM2TOM2 evaluation procedure using an example of one particular company.

An overview of the areas assessed, criteria and scoring is shown in the Table 4. 
Table 4 - Project Management Methods and Tools Oriented Maturity Model (1st part)

\begin{tabular}{|c|c|c|c|c|c|c|c|c|c|c|c|c|c|}
\hline \multirow{4}{*}{ Area } & \multirow{4}{*}{$\begin{array}{c}\text { Criteria } \\
\text { (Project Management Methods and } \\
\text { Tools) }\end{array}$} & \multicolumn{6}{|c|}{$\begin{array}{c}\text { The use of methods and tools of project management and } \\
\text { other criteria }\end{array}$} & \multirow{2}{*}{\multicolumn{6}{|c|}{$\begin{array}{l}\text { Coefficient according to the type of current projects and } \\
\text { the resulting maximum value after conversion using the } \\
\text { coefficient }\end{array}$}} \\
\hline & & \multirow[b]{3}{*}{$\begin{array}{l}\vec{\Xi} \\
\stackrel{0}{\Xi} \\
\stackrel{0}{0}\end{array}$} & \multicolumn{4}{|c|}{ Used } & \multirow{3}{*}{ 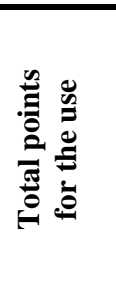 } & & & & & & \\
\hline & & & \multirow{2}{*}{ 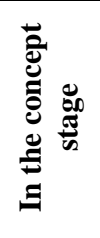 } & \multirow{2}{*}{ 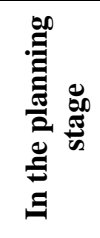 } & \multirow{2}{*}{ 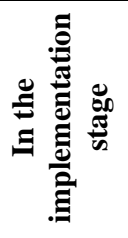 } & \multirow{2}{*}{ 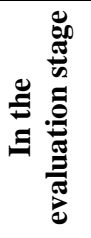 } & & \multicolumn{2}{|c|}{ Small } & \multicolumn{2}{|c|}{ Medium } & \multicolumn{2}{|c|}{ Large } \\
\hline & & & & & & & & ن & 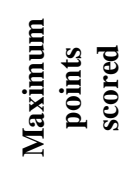 & ن & 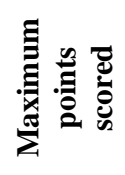 & ن & 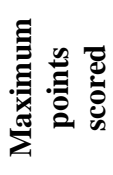 \\
\hline \multirow{8}{*}{$\begin{array}{c}\text { Time } \\
\text { Management }\end{array}$} & Gantt Chart & 0 & $\mathrm{~N}$ & 4 & 1 & 1 & 6 & 1 & 6 & 1 & 6 & 1 & 6 \\
\hline & CPM & 0 & \multirow{2}{*}{$\mathrm{N}$} & \multirow{2}{*}{6} & \multirow{2}{*}{1} & \multirow{2}{*}{1} & \multirow{2}{*}{8} & \multirow{2}{*}{0,5} & \multirow{2}{*}{4} & \multirow{2}{*}{1} & \multirow{2}{*}{8} & \multirow{2}{*}{1} & \multirow{2}{*}{8} \\
\hline & MPM & 0 & & & & & & & & & & & \\
\hline & PERT & 0 & \multirow{2}{*}{$\mathrm{N}$} & \multirow{2}{*}{6} & \multirow{2}{*}{1} & \multirow{2}{*}{1} & \multirow{2}{*}{8} & 0 & 0 & 05 & 4 & 1 & 8 \\
\hline & GERT & 0 & & & & & & 0 & 0 & , J & 4 & 1 & 8 \\
\hline & Critical Chain Method & 0 & $\mathrm{~N}$ & 6 & 1 & 1 & 8 & 0 & 0 & 0,5 & 4 & 1 & 8 \\
\hline & Monte Carlo Method & 0 & 3 & 4 & $\mathrm{~N}$ & 1 & 8 & 0 & 0 & 0,5 & 4 & 1 & 8 \\
\hline & $\sum$ & $\mathbf{0}$ & $\mathbf{N}$ & $\mathbf{N}$ & $\mathbf{N}$ & $\mathbf{N}$ & $\mathbf{N}$ & & 10 & & 6 & & \\
\hline & RBS & 0 & $\mathrm{~N}$ & 2 & 1 & 1 & 4 & 0,5 & 2 & 1 & 4 & 1 & 4 \\
\hline & \begin{tabular}{|l|} 
Resource Levelling \\
\end{tabular} & 0 & $\mathrm{~N}$ & 6 & 1 & 1 & 8 & 0,5 & 4 & 1 & 8 & 1 & 8 \\
\hline Resource & Responsibility Assignment Matrix & 0 & $\mathrm{~N}$ & 4 & 1 & 1 & 6 & 0,5 & 3 & 0,5 & 3 & 1 & 6 \\
\hline & Stakeholders Analysis & 0 & $\mathrm{~N}$ & 6 & 1 & 1 & 8 & 0,5 & 4 & 0,5 & 4 & 1 & 8 \\
\hline & $\Sigma$ & $\mathbf{0}$ & $\mathbf{N}$ & $\mathbf{N}$ & $\mathbf{N}$ & $\mathbf{N}$ & $\mathbf{N}$ & & 13 & & 9 & & \\
\hline & $\mathrm{CPM} / \mathrm{COST}$ & 0 & $\mathrm{~N}$ & 6 & 1 & 1 & 8 & 0 & 0 & 0,5 & 4 & 1 & 8 \\
\hline & NPV & 0 & 5 & 1 & $\mathrm{~N}$ & 2 & 8 & 05 & 4 & 1 & 8 & 1 & 8 \\
\hline Cost & $\mathrm{CBA}$ & 0 & $J$ & 1 & No & 2 & 0 & $0, J$ & 4 & 1 & 0 & 1 & 0 \\
\hline Management & Monitoring of Project Costs & 0 & $\mathrm{~N}$ & 2 & 4 & 2 & 8 & 1 & 8 & 1 & 8 & 1 & 8 \\
\hline & Monitoring of Project Cash Flows & 0 & $\mathrm{~N}$ & 2 & 4 & 2 & 8 & 1 & 8 & 1 & 8 & 1 & 8 \\
\hline & $\sum$ & $\mathbf{0}$ & $\mathbf{N}$ & $\mathbf{N}$ & $\mathbf{N}$ & $\mathbf{N}$ & $\mathbf{N}$ & & 20 & & 8 & & \\
\hline
\end{tabular}


Table 4 - Project Management Methods and Tools Oriented Maturity Model (2nd part)

\begin{tabular}{|c|c|c|c|c|c|c|c|c|c|c|c|c|c|}
\hline \multirow{4}{*}{ Area } & \multirow{4}{*}{$\begin{array}{c}\text { Criteria } \\
\text { (Project Management Methods and } \\
\text { Tools) }\end{array}$} & \multicolumn{6}{|c|}{$\begin{array}{l}\text { The use of methods and tools of project management and } \\
\text { other criteria }\end{array}$} & \multirow{2}{*}{\multicolumn{6}{|c|}{$\begin{array}{l}\text { Coefficient according to the type of current projects and } \\
\text { the resulting maximum value after conversion using the } \\
\text { coefficient }\end{array}$}} \\
\hline & & \multirow{3}{*}{ 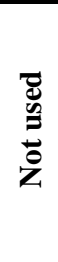 } & \multicolumn{4}{|c|}{ Used } & \multirow{3}{*}{ 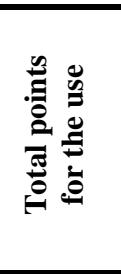 } & & & & & & \\
\hline & & & & & & & & \multicolumn{2}{|c|}{ Small } & \multicolumn{2}{|c|}{ Medium } & \multicolumn{2}{|c|}{ Large } \\
\hline & & & 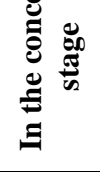 & 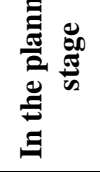 & 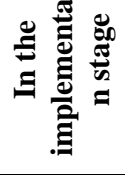 & 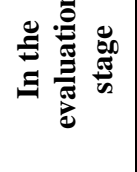 & & 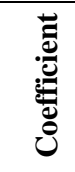 & 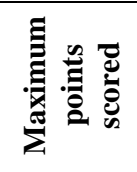 & 这 & 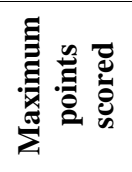 & Uू & 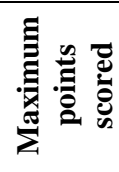 \\
\hline \multirow{6}{*}{$\begin{array}{c}\text { Risk } \\
\text { Management }\end{array}$} & RiBS & 0 & $\mathrm{~N}$ & 4 & 1 & 1 & 6 & 0,5 & 3 & 1 & 6 & 1 & 6 \\
\hline & Risk Register & 0 & $\mathrm{~N}$ & 6 & 1 & 1 & 8 & 0,5 & 4 & 1 & 8 & 1 & 8 \\
\hline & Ishikawa diagram & 0 & $\mathrm{~N}$ & 4 & 1 & 1 & 6 & 0 & 0 & 0,5 & 3 & 1 & 6 \\
\hline & $\begin{array}{l}\begin{array}{l}\text { Determination of the Expected Value of } \\
\text { the Risk }\end{array} \\
\end{array}$ & 0 & $\mathrm{~N}$ & 4 & 1 & 1 & 6 & 0,5 & 3 & 0,5 & 3 & 1 & 6 \\
\hline & Decision Tree Analysis & 0 & $\mathrm{~N}$ & 4 & 1 & 1 & 6 & 0 & 0 & 0,5 & 3 & 1 & 6 \\
\hline & $\Sigma$ & $\mathbf{0}$ & $\mathbf{N}$ & $\mathbf{N}$ & $\mathbf{N}$ & $\mathbf{N}$ & $\mathbf{N}$ & \multicolumn{2}{|c|}{10} & \multicolumn{2}{|c|}{23} & \multicolumn{2}{|c|}{32} \\
\hline \multirow{13}{*}{$\begin{array}{c}\text { Scope } \\
\text { Management }\end{array}$} & SWOT Analysis & 0 & 4 & 1 & $\mathrm{~N}$ & 1 & 6 & 0 & 0 & 0,5 & 3 & 1 & 6 \\
\hline & Feasibility Study & 0 & 6 & 1 & $\mathrm{~N}$ & 1 & 8 & 0 & 0 & 1 & 8 & 1 & 8 \\
\hline & SMART Method & 0 & 3 & $\mathrm{~N}$ & $\mathrm{~N}$ & 1 & 4 & 1 & 4 & 1 & 4 & 1 & 4 \\
\hline & Logical Framework & 0 & 6 & 1 & $\mathrm{~N}$ & 1 & 8 & 0,5 & 4 & 1 & 8 & 1 & 8 \\
\hline & PBS & 0 & $\mathrm{~N}$ & 4 & 1 & 1 & 6 & 0 & 0 & 0,5 & 3 & 1 & 6 \\
\hline & WBS & 0 & $\mathrm{~N}$ & 4 & 1 & 1 & 6 & 0,5 & 3 & 1 & 6 & 1 & 6 \\
\hline & Project Percent Complete Method & \multirow{3}{*}{0} & \multirow{3}{*}{$\mathrm{N}$} & \multirow{3}{*}{$\mathrm{N}$} & \multirow{3}{*}{5} & \multirow{3}{*}{1} & \multirow{3}{*}{6} & \multirow{3}{*}{1} & \multirow{3}{*}{6} & \multirow{3}{*}{0,5} & \multirow{3}{*}{3} & \multirow{3}{*}{0,5} & \multirow{3}{*}{3} \\
\hline & SSD & & & & & & & & & & & & \\
\hline & MTA & & & & & & & & & & & & \\
\hline & EVM & 0 & $\mathrm{~N}$ & $\mathrm{~N}$ & 7 & 1 & 8 & 0 & 0 & 0,5 & 4 & 1 & 8 \\
\hline & Lessons Learned & 0 & $\mathrm{~N}$ & $\mathrm{~N}$ & $\mathrm{~N}$ & 8 & 8 & 0,5 & 4 & 1 & 8 & 1 & 8 \\
\hline & Agile Methods & 0 & 2 & 2 & 2 & 2 & 8 & 0,5 & 4 & 1 & 8 & 1 & 8 \\
\hline & $\sum$ & $\mathbf{0}$ & $\mathbf{N}$ & $\mathbf{N}$ & $\mathbf{N}$ & $\mathbf{N}$ & $\mathbf{N}$ & & 25 & & 55 & & 5 \\
\hline
\end{tabular}


Table 4 - Project Management Methods and Tools Oriented Maturity Model (3rd part)

\begin{tabular}{|c|c|c|c|c|c|c|c|c|c|c|c|c|c|}
\hline \multirow{4}{*}{ Area } & \multirow{4}{*}{$\begin{array}{c}\text { Criteria } \\
\text { (Project Management Methods and } \\
\text { Tools) }\end{array}$} & \multicolumn{6}{|c|}{$\begin{array}{c}\text { The use of methods and tools of project management and } \\
\text { other criteria }\end{array}$} & \multirow{2}{*}{\multicolumn{6}{|c|}{$\begin{array}{l}\text { Coefficient according to the type of current projects and } \\
\text { the resulting maximum value after conversion using the } \\
\text { coefficient }\end{array}$}} \\
\hline & & \multirow[b]{3}{*}{ 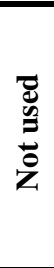 } & \multicolumn{4}{|c|}{ Used } & \multirow{3}{*}{ 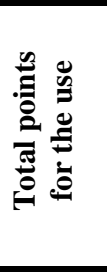 } & & & & & & \\
\hline & & & & .00 & & & & & mall & & dium & & Irge \\
\hline & & & 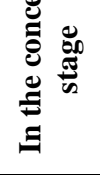 & 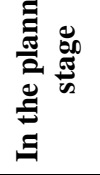 & 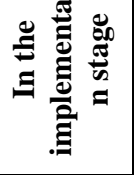 & 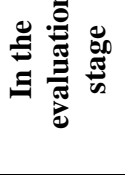 & & : & 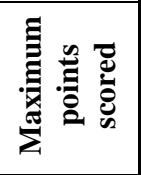 & : & 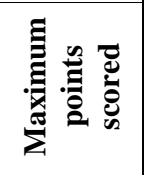 & 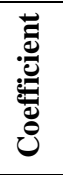 & 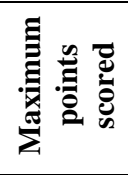 \\
\hline \multirow{8}{*}{$\begin{array}{l}\text { Organizational } \\
\text { support to the } \\
\text { projects and } \\
\text { staff training }\end{array}$} & Staff education in PM & 0 & 2 & 2 & 2 & 2 & 8 & 1 & 8 & 1 & 8 & 1 & 8 \\
\hline & $\begin{array}{l}\text { Use of outside advisors and project } \\
\text { managers }\end{array}$ & 0 & 2 & 2 & 2 & 1 & 7 & 0 & 0 & 1 & 7 & 1 & 7 \\
\hline & Project management within units & 0 & 1 & 1 & 1 & 1 & 4 & 1 & 4 & 1 & 4 & 1 & 4 \\
\hline & Matrix organizational structure & 0 & 1 & 2 & 2 & 1 & 6 & 0 & 0 & 1 & 6 & 1 & 6 \\
\hline & Project organizational structure & 0 & 2 & 2 & 2 & 2 & 8 & 0 & 0 & 0,5 & 4 & 1 & 8 \\
\hline & $\begin{array}{l}\text { Organizational Standards to Support } \\
\text { Project Management }\end{array}$ & 0 & 2 & 2 & 2 & 2 & 8 & 0,5 & 4 & 1 & 8 & 1 & 8 \\
\hline & PMO & 0 & 2 & 2 & 2 & 2 & 8 & 0 & 0 & 0,5 & 4 & 1 & 8 \\
\hline & $\sum$ & $\mathbf{0}$ & $\mathbf{N}$ & $\mathbf{N}$ & $\mathbf{N}$ & $\mathbf{N}$ & $\mathbf{N}$ & \multicolumn{2}{|c|}{16} & \multicolumn{2}{|c|}{41} & \multicolumn{2}{|c|}{49} \\
\hline \multirow{4}{*}{$\begin{array}{c}\text { Software } \\
\text { support of } \\
\text { project } \\
\text { management }\end{array}$} & Simple cloud or freeware solutions & 0 & 1 & 2 & 2 & 1 & 6 & 1 & 6 & 0,5 & 3 & 0,5 & 3 \\
\hline & $\begin{array}{l}\text { Specialized application with a wide range } \\
\text { of functionality }\end{array}$ & 0 & 2 & 2 & 2 & 2 & 8 & 0,5 & 4 & 1 & 8 & 1 & 8 \\
\hline & Complex SW support of PM & 0 & 2 & 2 & 2 & 2 & 8 & 0 & 0 & 0,5 & 4 & 1 & 8 \\
\hline & $\sum^{*}$ & $\mathbf{0}$ & $\mathbf{N}$ & $\mathbf{N}$ & $\mathbf{N}$ & $\mathbf{N}$ & $\mathbf{N}$ & \multicolumn{2}{|c|}{6} & \multicolumn{2}{|c|}{8} & \multicolumn{2}{|c|}{8} \\
\hline \multicolumn{2}{|l|}{ Maximum score } & $\mathbf{0}$ & $\mathbf{N}$ & $\mathbf{N}$ & $\mathbf{N}$ & $\mathbf{N}$ & $\mathbf{N}$ & \multicolumn{2}{|c|}{100} & \multicolumn{2}{|c|}{200} & \multicolumn{2}{|c|}{250} \\
\hline
\end{tabular}

in the case of evaluating software support, corresponds to the maximum number of points scored is not the sum, but the best option $\mathrm{N}$ not evaluated or is not relevant to the assessment Source: Authors 
To specify each level, we chose the linear distribution of the total maximum score into five levels (similarly to most PMMMs), but it is necessary to evaluate the organizations separately according to the prevailing type of projects carried out. Summary of proposed project management maturity levels and range of scores of different management maturity levels with respect to the prevailing type of the projects carried out is given in Table 5.

Table 5 - Project Management Maturity Levels by PM2TOM2

\begin{tabular}{|c|c|c|c|}
\hline Project Management Maturity Level & Small project & $\begin{array}{c}\text { Medium } \\
\text { project }\end{array}$ & Large project \\
\hline Low Management Maturity Level & $0-20$ & $0-40$ & $0-50$ \\
\hline Lower Medium Management Maturity Level & $21-40$ & $41-80$ & $51-100$ \\
\hline Medium Management Maturity Level & $41-60$ & $81-120$ & $101-150$ \\
\hline Advanced Management Maturity Level & $61-80$ & $121-160$ & $151-200$ \\
\hline High Management Maturity Level & $81-100$ & $161-200$ & $201-250$ \\
\hline
\end{tabular}

Legend: The distribution of the scoring is even from the point of view of the individual assessment levels. The difference between the types of projects corresponds to the different extent of the use of project management methods and tools.

Source: Authors

A detailed assessment of the project management maturity level of the organization can be focused on individual sub-areas to assess in which areas the project management maturity level of the organization achieves good results, in comparison with the maximum amount of points scored in which it achieves poorer results and where there thus is a room for improvement.

On the basis of verification in applying PM2TOM2 in practice, the following procedure is recommended:

1. Collection of data in the organization carrying out the projects

In this step, the organization must collect data, either by its own or with the help of an external entity. A suitable partner for the transmission of information for the solving organization is a specialist in project management, the head of PMO (if present in the organization) or the head of a relevant organizational unit in charge of project implementation. Data can also be obtained from a number of partners on the part of the organization carrying out the projects, e.g. from members of project teams and project managers, but it is necessary to consolidate and always obtain a single output for the group to all the criteria assessed. It is also necessary to get the information as to what is the predominant type of projects carried out, whether it is mainly small, medium or large projects that are implemented.

2. Analysis of the data obtained using the model designed
Individual criteria in all areas are assessed and awarded with points according to the extent of use of the respective criteria in individual stages of PLC. Subsequently, the scores are adjusted using the coefficients with respect to the prevailing type of current projects and the total number of points is calculated (see Table 1 and Annex A).

3. Evaluation of project management maturity

The final score for all areas is compared with the proposed range of points for individual project management maturity levels (see Table 2 and Annex A) and the achieved project management maturity level of the organization is determined.

4. Use of the evaluation results

Using the final scoring in individual areas, it is possible to draw conclusions as to in which areas project management methods and tools are used to a limited extent, where they are underused with regard to the various stages of PLC, and possibly where they are used inappropriately with regard to the type of prevailing projects. Similarly, it is possible to assess other criteria. This assessment can then be used for proposing changes in practice.

PM2TOM2 is not a clearly defined alternative to the existing models oriented mainly to the assessment of project management processes, but in pursuit of a detailed assessment of the project management maturity level we can use this model to get a broader idea of project management maturity in the assessed 
organization, particularly of the extent to which project management methods and tools are used. The result of the evaluation can then be used for setting changes intended to improve project management maturity. Moreover, in comparison with the standard models used, this is a less robust model that is not so demanding in terms of processing.

\section{VALIDATION OF THE PM2TOM2 IN PRACTICE}

Table 6 - Project Management Maturity Assessment in Monitored Chemical Industry Companies by PM2TOM2

\begin{tabular}{|c|c|c|c|c|c|c|c|c|c|}
\hline \multirow{2}{*}{ Area } & \multirow{2}{*}{$\begin{array}{c}\text { Criteria } \\
\text { (Project Management Methods } \\
\text { and Tools) } \\
\end{array}$} & \multicolumn{8}{|c|}{ Company and its score } \\
\hline & & $\mathbf{A}$ & B & $\mathbf{C}$ & D & $\mathbf{E}$ & $\mathbf{F}$ & G & $\mathbf{H}$ \\
\hline \multirow{7}{*}{$\begin{array}{c}\text { Time } \\
\text { management }\end{array}$} & Gantt Chart & 0 & 0 & 6 & 0 & 0 & 6 & 0 & 0 \\
\hline & \begin{tabular}{|l|} 
CPM \\
MPM
\end{tabular} & 0 & 0 & 8 & 0 & 0 & 8 & 0 & 0 \\
\hline & PERT & \multirow{2}{*}{0} & \multirow{2}{*}{0} & \multirow{2}{*}{0} & \multirow{2}{*}{0} & \multirow{2}{*}{0} & \multirow{2}{*}{0} & \multirow{2}{*}{0} & \multirow{2}{*}{0} \\
\hline & GERT & & & & & & & & \\
\hline & Critical Chain Method & 0 & 0 & 8 & 0 & 0 & 0 & 0 & 0 \\
\hline & Monte Carlo Method & 0 & 0 & 0 & 0 & 0 & 0 & 0 & 0 \\
\hline & $\sum$ & $\mathbf{0}$ & $\mathbf{0}$ & 22 & $\mathbf{0}$ & $\mathbf{0}$ & 14 & $\mathbf{0}$ & $\mathbf{0}$ \\
\hline \multirow{5}{*}{$\begin{array}{c}\text { Resource } \\
\text { management }\end{array}$} & RBS & 0 & 0 & 4 & 0 & 4 & 4 & 0 & 0 \\
\hline & Resource Levelling & 0 & 0 & 8 & 0 & 8 & 8 & 0 & 0 \\
\hline & Responsibility Assignment Matrix & 3 & 6 & 6 & 6 & 6 & 6 & 3 & 6 \\
\hline & Stakeholders Analysis & 0 & 0 & 0 & 0 & 8 & 0 & 0 & 8 \\
\hline & $\Sigma$ & 3 & 6 & 18 & 6 & 26 & 18 & 3 & 14 \\
\hline \multirow{6}{*}{$\begin{array}{c}\text { Cost } \\
\text { management }\end{array}$} & CPM/COST & 0 & 0 & 0 & 0 & 0 & 8 & 0 & 0 \\
\hline & NPV & \multirow{2}{*}{8} & \multirow{2}{*}{8} & \multirow{2}{*}{8} & \multirow{2}{*}{8} & \multirow{2}{*}{8} & \multirow{2}{*}{8} & \multirow{2}{*}{0} & o \\
\hline & CBA & & & & & & & & 8 \\
\hline & Monitoring of Project Costs & 8 & 8 & 8 & 8 & 8 & 8 & 0 & 8 \\
\hline & Monitoring of Project Cash Flows & 8 & 8 & 8 & 8 & 8 & 8 & 0 & 8 \\
\hline & $\sum$ & 24 & 24 & 24 & 24 & 24 & 32 & $\mathbf{0}$ & 24 \\
\hline & RiBS & 6 & 0 & 6 & 0 & 0 & 6 & 6 & 6 \\
\hline & Risk Register & 0 & 0 & 0 & 0 & 0 & 0 & 0 & 0 \\
\hline & Ishikawa diagram & 0 & 6 & 6 & 0 & 0 & 6 & 0 & 0 \\
\hline management & $\begin{array}{l}\text { Determination of the Expected } \\
\text { Value of the Risk }\end{array}$ & 3 & 0 & 6 & 0 & 0 & 6 & 3 & 6 \\
\hline & Decision Tree Analysis & 0 & 0 & 6 & 0 & 0 & 0 & 0 & 0 \\
\hline & $\sum$ & 9 & 6 & 24 & $\mathbf{0}$ & $\mathbf{0}$ & 18 & 9 & 12 \\
\hline & SWOT Analysis & 3 & 6 & 6 & 6 & 0 & 6 & 3 & 6 \\
\hline & Feasibility Study & 4 & 8 & 0 & 0 & 8 & 8 & 0 & 8 \\
\hline management & SMART Method & 4 & 4 & 4 & 4 & 0 & 4 & 0 & 4 \\
\hline & Logical Framework & 0 & 0 & 8 & 0 & 0 & 0 & 0 & 0 \\
\hline & PBS & 0 & 0 & 0 & 0 & 0 & 0 & 0 & 0 \\
\hline
\end{tabular}

the assessment of project management maturity in eight selected enterprises of the chemical industry in the Czech Republic, see Table 6. Using this model, it is possible to obtain information on the project management maturity in individual companies in the assessed areas, but also across companies under consideration, and to assess the strengths and weaknesses of project management in individual companies, but also within the chemical industry. 


\begin{tabular}{|c|c|c|c|c|c|c|c|c|c|}
\hline & WBS & 0 & 0 & 0 & 0 & 0 & 6 & 0 & 0 \\
\hline \multirow{2}{*}{ Area } & \multirow{2}{*}{$\begin{array}{c}\text { Criteria } \\
\text { (Project Management Methods } \\
\text { and Tools) }\end{array}$} & \multicolumn{8}{|c|}{ Company and its score } \\
\hline & & $\mathbf{A}$ & B & C & D & $\mathbf{E}$ & $\mathbf{F}$ & G & $\mathbf{H}$ \\
\hline \multirow{7}{*}{$\begin{array}{c}\text { Scope } \\
\text { management }\end{array}$} & Project Percent Complete Method & \multirow{3}{*}{3} & \multirow{3}{*}{3} & \multirow{3}{*}{3} & \multirow{3}{*}{3} & \multirow{3}{*}{3} & \multirow{3}{*}{3} & \multirow{3}{*}{0} & \multirow{3}{*}{3} \\
\hline & SSD & & & & & & & & \\
\hline & MTA & & & & & & & & \\
\hline & EVM & 0 & 0 & 8 & 0 & 0 & 0 & 0 & 0 \\
\hline & Lessons Learned & 8 & 0 & 8 & 0 & 8 & 8 & 0 & 8 \\
\hline & Agile Methods & 0 & 0 & 0 & 0 & 0 & 8 & 0 & 0 \\
\hline & $\sum$ & 22 & 21 & 37 & 13 & 19 & 43 & 3 & 29 \\
\hline \multirow{8}{*}{$\begin{array}{l}\text { Organizational } \\
\text { support to the } \\
\text { projects and staff } \\
\text { training }\end{array}$} & Staff education in PM & 0 & 8 & 8 & 8 & 0 & 8 & 0 & 0 \\
\hline & $\begin{array}{l}\text { Use of outside advisors and project } \\
\text { managers }\end{array}$ & 7 & 0 & 7 & 7 & 7 & 7 & 0 & 0 \\
\hline & Project management within units & 0 & 0 & 0 & 0 & 0 & 0 & 4 & 0 \\
\hline & Matrix organizational structure & 6 & 6 & 0 & 6 & 6 & 6 & 0 & 6 \\
\hline & Project organizational structure & 0 & 0 & 8 & 0 & 0 & 0 & 0 & 0 \\
\hline & $\begin{array}{l}\text { Organizational Standards to Support } \\
\text { Project Management }\end{array}$ & 0 & 8 & 8 & 8 & 8 & 8 & 8 & 0 \\
\hline & PMO & 0 & 0 & 0 & 0 & 0 & 0 & 4 & 0 \\
\hline & $\sum$ & 13 & 22 & 31 & 29 & 21 & 29 & 16 & 6 \\
\hline \multirow{4}{*}{$\begin{array}{c}\text { Software support } \\
\text { of project } \\
\text { management }\end{array}$} & Simple cloud or freeware solutions & 0 & 0 & 0 & 0 & 0 & 0 & 0 & 3 \\
\hline & $\begin{array}{l}\text { Specialized application with a wide } \\
\text { range of functionality }\end{array}$ & 0 & 8 & 8 & 8 & 0 & 8 & 0 & 0 \\
\hline & Complex SW support of PM & 0 & 0 & 0 & 0 & 0 & 0 & 0 & 0 \\
\hline & $\sum$ & $\mathbf{0}$ & 8 & 8 & 8 & $\mathbf{0}$ & 8 & $\mathbf{0}$ & 3 \\
\hline \multicolumn{2}{|c|}{ Total number of points scored } & 71 & 87 & 164 & 80 & 90 & 162 & 31 & 88 \\
\hline
\end{tabular}

Source: Authors

With regard to the size of the projects carried out (see Table 3) and the project management maturity rating scale (see Table 5), the project management maturity can be assessed as a low management maturity level in Company G, a lower medium management maturity level in Companies $\mathrm{A}, \mathrm{B}, \mathrm{D}, \mathrm{E}$ and $\mathrm{H}$ and an advanced management maturity level in Companies $\mathrm{C}$ and $\mathrm{F}$.

As part of the PM2TOM2 verification, an overview was obtained of the overall maturity project management of the companies in question as well as that of the project management maturity in the project management sub-areas and support. Applying this model, the user will primarily get an overview of the extent of the use of project management methods and tools in the practice of the company assessed, which gives a very significant indication of the level of application of the project management procedures in practice.

We can state that PM2TOM2 is a userfriendly model that enables competent business managers to assess the project management maturity in their companies and, at the same time, to identify the areas that need attention and the project management methods that need to be implemented. In addition, it is a model whose application does not require the involvement of external project managers or companies, which does not increase costs.

It is also relevant to mention the limitation of PM2TOM2. Using this model, we can get general information about project management maturity, but the detailed outputs mainly concern project management methods and tools. Thus, the applicability of the model is limited in the case that companies apply specific project management practices, for example, if they only apply agile management in full extent.

Another possible direction of research in the evaluation of project management maturity could lead to a modification of PM2TOM2 for the needs of management of programs and project portfolio. Under this modification, it would be necessary to 
extend the existing project management methods and tools with the methods and tools used to manage programs and portfolios of projects and broaden the criteria in the area under consideration organizational support to the projects and staff training.

\section{CONCLUSION}

The study has documented that project management maturity models so far discussed in theory and applied in practice are organizationoriented or process-oriented models. Alternatively, these are models focused on project management or industry-focused PMMMs. However, these models do not focus on the use of specific project management methods and tools, the appropriate application of which is a key prerequisite for successful project management.

The aim of the study was to design and verify a user-friendly PMMM to evaluate the project management maturity based on the assessment of usage of project management tools and methods within each stage of the project life cycle taking into account the predominant type of projects implemented. With no significant demands in terms of competence, organization and administration, the designed PM2TOM2 is a model that allows a comprehensive and inexpensive assessment of project management methods and tools in the organization and evaluation of the project management maturity of the organization. Using this information, competent managers of the individual organizations can draw conclusions and take adequate measures regarding applied methods and tools of project management.

\section{REFERENCES}

Adamek, M. et al. (2013). Certification of project management in organizations - a reference model. Brno: IPMA - Spolecnost pro projektove rizeni.

Ahlemann, F. (2009). Towards a conceptual reference model for project management information systems. International Journal of Project Management, 27(1), 19-30. doi: 10.1016/j.ijproman.2008.01.008

Albrecht, J. C. \& Spang, K. (2016). Disassembling and reassembling project management maturity. Project Management Journal, 47(5), 18-35.

Albrecht, J. C. \& Spang, K. (2014). Linking the benefits of project management maturity to project complexity. International Journal of Managing
Projects in Business, 7(2), 285-301. doi: 10.1108/ijmpb-08-2013-0040

Ali, A. S. B., Anbari, F. T. \& Money, W. H. (2008). Impact of organization and project factors on acceptance and usage of project management software and perceived project success. Project Management Journal, 39(2), 5-33. doi: 10.1002/pmj.20041

Andersen, E. S. \& Jenssen, S. A. (2003). Project maturity in organizations. International Journal of Project Management, 21, 457-461.

Archibald, R. D. (2013). A global system for categorizing projects. Project Perspectives, 35(1), 611 .

Association for Project Management. (2012). APM body of knowledge. High Wicombe: Association for Project Management.

Axelos Limited. (2013). Prince 2 maturity model (P2MM). Retrieved in December 12, 2016, from https://www.axelos.com/Corporate/media/Files/P3 M3\%20Model/PRINCE2_Maturity_Model_P2MM. pdf

Axelos Limited. (2010). P3M3 project management self - assessment. Retrieved in December 17, 2016, from

https://www.axelos.com/Corporate/media/Files/P3 M3\%20Model/P3M3_Self_Assess_Project.pdf

Backlund, F., Chronéer, D. \& Sundqvist, E. (2014). Project management maturity models - a critical review a case study within Swedish engineering and construction organizations. Procedia - Social and Behavioral Sciences, 119, 837-846. doi: 10.1016/j.sbspro.2014.03.094

Beck, K. et al. (2001). Manifesto for agile software development. Retrieved in November 1, 2016, from http://www.agilemanifesto.org/

Besner, C. \& Hobbs, B. (2012). An empirical identification of project management toolsets and a comparison among project types. Project Management Journal, 39(5), 24-46. doi: 10.1002/pmj.21292

Braglia, M. \& Frosolini, M. (2012). An integrated approach to implement project management information systems within the extended enterprise. International Journal of Project Management, 32(1), 18-29. doi: 10.1016/j.ijproman.2012.12.003

Bryde, D. J. (2003). Modelling project management performance. The International Journal of Quality \& 
Reliability Management, 20(2), 228-253. doi: $10.1108 / 02656710310456635$

Campbell, H. \& Brown, R. (2003). Benefit-cost analysis. Cambridge: Cambridge University Press.

Carrilo, P. et al. (2013). When will we learn? Improving lessons learned practice in construction. International Journal of Project Management, 31(4), 567-578. doi: 10.1016/j.ijproman.2012.10.005

Chang, X. \& Wei, B. (2014). The application of project management maturity model. Paper presented at the $2^{\text {nd }}$ International Conference on Sensors, Measurement and Intelligent Materials, Guangzhou, Beijing, China. doi: 10.4028/www.scientific.net/amm.475-476.1707

CMMI Institute. (2016). Background on CMMI - a framework for improving performance. Retrieved in November 16, 2016, from http://cmmiinstitute.com/about-cmmi-institute

Couillard, J., Garon, S. \& Riznic, J. (2009). The logical framework approach - millennium. Project Management Journal, 40(4), 31-44. doi: 10.1002/pmj.20117

Crawford, J. K. (2015). Project Management Maturity Model. Boca Raton: CRP Press.

Crawford, L., Hobbs, J. \& Turner, R. (2004). Project categorization systems and their use in organisations: an empirical study. Paper presented at the PMI Research Conference 2004, Newton Square, U.S.A.

Dolezal, J. et al. (2012). Project management by IPMA. Prague: Grada Publishing.

ESI International. (2016). Assessing project management maturity. Retrieved in November 20, 2016, from https://www.strategyex.com/

Farrokh, J. \& Mansur, A. K. (2013). Project management maturity models and organizational project management maturity model (OPM3): A critical morphological evaluation. International Scholarly and Scientific Research \& Innovation, 7(5), 68-71.

Fengyong, Z. \& Renhui, L. (2007). Study on framework of construction project management maturity model. Paper presented at $4^{\text {th }}$ International Conference on Service Systems and Service Management, Chengdu, China. doi: 10.1109/icsssm.2007.4280298
Fiala, P. (2008). Management of projects. Prague: Oeconomia.

Fincher, A. \& Levin, G. (1997). Project management maturity model. Paper presented at PMI 28th Annual Seminars \& Symposium, Upper Darby, Pa, U.S.A.

Fuessinger, E. (2006). Maturities of project-oriented companies of about 15 project oriented-nations. Retrieved in January 10, 2017, from http://www.icoste.org/Slovenia2006Papers/icecFina 100100.pdf

Gareis, R. (2005). Happy projects! Vienna: Manz.

Gartner Inc. (2014). ITscore overview for program and portfolio management. Retrieved in November 23, 2016, from https://www.gartner.com/doc/2837917/itscoreoverview-program-portfolio-management

Goldratt, E. M. (1997). Critical chain. New York: North River Press.

Haponava, T. \& Al-Jibouri, S. (2009). Identifying key performance indicators for use in control of preproject stage process in construction. International Journal of Productivity and Performance Management, $58(2), \quad$ 160-173. doi: $10.1108 / 17410400910928743$

Harrington, H. J. (2006). Project management excellence: the art of excelling in project management. Chico: Paton Press.

Haukka, M. (2013). Maturity levels of project portfolio management (PPM) and how to set your own target level. PM World Journal, 2(3), 1-13.

Hertogh, M. et al. (2008). Managing large infrastructure projects. Ultrecht: AT Osborne B.V.

Hillier, F. S. \& Lieberman, G. J. (2005). Introduction to operations research. New York: McGraw-Hill.

Hillson, D. (2003). Assessing organizational project management capability. Journal of Facilities Management, 2(3), 298-311. doi: $10.1108 / 14725960410808276$

Hillson, D. (2001). Benchmarking Organizational Project Management Capability. Paper presented at PMI Annual Seminars \& Symposium 2001, Nashville, Tennessee, U.S.A.

Hopkinson, M. (2010). The project risk maturity model. London: Routledge. doi: $10.4324 / 9781315237572$ 
Hrazdilova Bockova, K. (2009). Future scenarios of Czech project management. Economics and management, 12(3), 6-18.

International Project Management Association. (2016). Reference model for IPMA Delta. Retrieved in November 19, 2016, from http://www.ipma.world/certification/certifyorganisations/delta-reference-model/

Interthink Consulting. (2016). Organizational project management assessment. Retrieved in December 2, 2016, from http://interthink.ca/services/project-advisoryservices/organizational-project-managementassessment/

Jain, A. (1998). Project management maturity model: A new outlook. Paper presented at $14^{\text {th }}$ IPMA World Congress on Project Management, Ljubljana, Slovenia.

Joslin, R. \& Müller, R. (2015). Relationship between a project management methodology and project success in different project governance contexts. International Journal of Project Management, 33(6), 1377-1392. doi: 10.1016/j.ijproman.2015.03.005

Jugdev, K. (2012). Learning from lessons learned: project management research programme. American Journal of Economics and Business Administration, 4(1), 13-22.

Kaiser, M. G. \& Ahlemann, F. (2010). Measuring project management information systems success towards a conceptual model and survey instrument. Retrieved in November 6, 2016, from http://is2.1se.ac.uk/asp/aspecis/20100126.pdf

Kerzner, H. (2014). Kerzner project management maturity assessment. Retrieved in November 2, 2016, from https://www.iil.com/kpm3/how_kpm3_works.asp

Kerzner, H. (2001). Strategic planning for project management using a project management maturity model. New York: John Wiley \& Sons.

Killen, C. P. \& Hunt, R. A. (2013). Robust project portfolio management: capability evolution and maturity. International Journal of Managing Projects in Business, 6/1, 131-151. doi: $10.1108 / 17538371311291062$

Koerner, M. (2005). Declaration of interdependence. Retrieved in November 7, 2016, from http://pmdoi.org/
Kostalova, J. (2015). The assessment of the project management maturity in the Czech Republic with focus on projects co-financed by European funds and projects of the chemical industry enterprises. Ph.D. Thesis. Pardubice: University of Pardubice.

Kostalova, J. \& Tetrevova, L. (2016). Application of project management methods and tools with respect to the project life cycle and the project type. Paper presented at $9^{\text {th }}$ International Scientific Conference Business and Management 2016, Lithuania, Vilnius. doi: $10.3846 / \mathrm{bm} .2016 .03$

Kostalova, J., Tetrevova, L. \& Svedik, J. (2015). Support of project management methods by project management information system. Procedia-Social and Behavioural Sciences, 210, 96-104. doi: 10.1016/j.sbspro.2015.11.333

Kwak, Y. H., \& Ibbs, C. W. (2002). Project management process maturity (PM) ${ }^{2}$ model. Journal of Management in Engineering, 18, 150-155.

Kwak, Y. H., Sadatsafavi, H., Walewski, J. \& Williams, N. L. (2015) Evolution of project based organization: A case study. International Journal of Project Management, 33(8), 1652-1664. doi: 10.1016/j.ijproman.2015.05.004

Lappe, M. \& Spang, K. (2014). Investment in project management are profitable: A case study-based analysis of the relationship between the costs and benefits of project management. International Journal of Project Management, 32(4), 603-612. doi: 10.1016/j.ijproman.2013.10.005

Lee-Kwang, H. \& Favrel, J. (1988). The SSD graph: a tool for project scheduling and visualization. IEEE Transactions on Engineering Management, 35(1), 25-29.

Lester, A. (2007). Project management, planning and control. Oxford: Elsevier. doi: 10.1016/b978075066956-6/50031-9

Levene, R. A., Bentley, A. E. \& Jarvis, G. S. (1995). The scale of project management. Paper presented at $26^{\text {th }}$ Annual Project Management Institute Seminar Symposium. New Orleans, U.S.A.

Lianying, Z., Jing, H. \& Xinxing, Z. (2012). The project management maturity model and application based on PRINCE 2. Procedia Engineering, 29, 3691-3697. doi: 10.1016/j.proeng.2012.01.554

Lubianiker, S. (2000). Opening the book on the open maturity model. Retrieved in November 12, 2016, 
from http://www.pmi.org/learning/open-maturitymodel-principles-tools-4637? id=4637

Maravas, A. \& Pantouvakis, J. (2012). Project cash flow analysis in the presence of uncertainty in activity duration and cost. International Journal of Project Management, 30(3), 374-384. doi: 10.1016/j.ijproman.2011.08.005

Markensteijn, P. (2001). PM3-model en deze website. Retrieved in January 5, 2017, from http://www.markensteijn.com/index.php/98-hetpm3-model/292-over-het-pm3-model-en-dezewebsite

Maylor, H. (2010). Project management. Harlow: Pearson Education.

Meisner, R. (2007). MINCE - a framework for organizational maturity. Zaltbommel: van Haren Publishing.

Melnic, A. \& Puiu, T. (2011). The management of human resources within projects: the structures of the project team, the responsibility. Economy Transdisciplinary Cognition, 14(1), 476-484.

Meredith, J. R., \& Mantel, S. J. (2012). Project management a managerial approach. Hoboken: John Wiley \& Sons.

Mian, M. A. (2011). Project economics and decision analysis: deterministic models. Tulsa: PennWell Books.

Mullaly, M. (2014). If maturity is the answer, then exactly what was the question? International Journal of Managing Projects in Business, 7(5), 169-185. doi: 10.1108/ijmpb-09-2013-0047

Müller, R. et al. (2013). A relational typology of project management offices. Project Management Journal, 44(1), 59-76. doi: 10.1002/pmj.21321

Nikkhoua, S., Taghizadehb, K. \& Hajiyakhchalic, S. (2016). Designing a Portfolio management maturity model (Elena). Procedia - Social and Behavioural Sciences, 226, 318-325. doi: 10.1016/j.sbspro.2016.06.194

Norman, E. S., Brotherton, S. A. \& Fried, R. T. (2008). Work breakdown structures: the foundation for project management excellence. Hoboken: John Wiley \& Sons.

Oellgaard, M. J. (2013). The performance of project life cycle methodology in practice. Project Management Journal, 44(5), 65-83. doi: 10.1002/pmj.21357
Pasian, B. (2014). Extending the concept and modularization of project management maturity with adaptable, human and customer factors. International Journal of Managing Projects in Business, 7(2), 186-214. doi: 10.1108/ijmpb-012014-0006

Patanakul, P., Iewwongcharoen, B. \& Milosevic, D. (2010). An empirical study on the use of project management tools and techniques across project lifecycle and their impact on project success. Journal of General Management, 35(3), 41-65. doi. $10.1177 / 030630701003500304$

Pcubed. (2016). Implementing project and performance management tools. Retrieved in November $\quad 8, \quad 2016, \quad$ from http://www.pcubed.com/bulletins/implementingproject-and-performance-management-tools

PM Solutions. (2013). What is the Project Management Maturity Model (PMMM)? Retrieved in November 7, 2016, from http://www.pmsolutions.com/resources/view/whatis-the-project-management-maturity-model/

Poster, K. \& Applegarth, M. (2006). Project management. Prague: Portal.

Prado, D. (2002). Foundations of Prado PM Maturity Model. Retrieved in November 4, 2016, from http://www.maturityresearch.com/novosite/biblio/fo undations-prado-pmmm.pdf

Project Management Institute. (2004). A guide to the project management body of knowledge. Newton Square: PMI. doi: 10.1109/ieeestd.1999.89431

Project Management Institute. (2001). Organizational project management maturity model (OPM3). Newton Square: PMI. doi: 10.1201/9781420028942.axa

Prosci. (2004). Prosci's change management maturity model ${ }^{\mathrm{TM}}$. Retrieved in November 29, 2016, from http://www.change-management.com/ProsciCM-Maturity-Model-writeup.pdf

PwC. (2014). When will you think differently about programme delivery? Retrieved in November 26, 2016, from https://www.pwc.com/gx/en/consultingservices/portfolio-programme-

management/assets/global-ppm-survey.pdf

Rad, P. F. \& Cioffi, D. F. (2004). Work and resource breakdown structure for formalized bottom-up estimating. Cost Engineering, 46(2), 31-37. 
Ravindran, A. R. (2007). Operations research and management science handbook. Boca Raton: Taylor \& Francis Group. doi: 10.1201/9781420009712

Remy, R. (1997). Adding focus to improvement efforts with PM3. Retrieved in November 2, 2016, from http://www.pmi.org/learning/adding-focusimprovement-efforts-pm3-5147?id=5147

Robbins, S. P. \& Coulter, M. (2004). Management. Prague: Grada Publishing.

Rosenau, M. D. (2009). Management of projects. Brno: Computer Press.

Shi, Q. (2011). Rethinking the implementation of project management: a value adding path map approach. International Journal of Project Management, 29(3), 295-305. doi: 10.1016/j.ijproman.2010.03.007

Soares, F. S. F. \& Meira, S. R. (2014). AP3M-SW an agile project management maturity model for software organizations. Paper presented at $9^{\text {th }}$ International Conference on Software Engineering Advanced ICSEA 2014, Nice, France.

Solanki, P. (2009). Earned value management: integrated view of cost and schedule performance. New Delhi: Global India Publications.

Souza, T. F. \& Gomes, C. F. S. (2015). Assessment of maturity in project management: a bibliometric study of main models. Procedia Computer Science, 55, 92-101. doi: 10.1016/j.procs.2015.07.012

Spalek, S. (2015). Establishing a conceptual model for assessing project management maturity in industrial companies. International Journal of Industrial Engineering, 22(2), 301-313.

Storms, K. (2008). Earned value management implementation in an agency capital improvement program. Cost Engineering, 50(12), 17-40.

Sukhoo, A. et al. (2007). An evolutionary software project management maturity model for Mauritius. Interdisciplinary Journal of Information, Knowledge and Management, 2(14), 99-118. doi: $10.28945 / 3158$

Tahri, H. \& Drissi-Kaitouni, O. (2015). New design for calculation project management maturity (PMM). Procedia-Social and Behavioral Sciences, 181, 171-177. doi: https://doi.org/10.1016/j.sbspro.2015.04.878

Tetrevova, L. (2006). Project financing. Prague: Professional Publishing.
Turner, J. R. \& Cochrane, R. A. (1993). Goals-andmethods matrix: coping with projects with ill defined goals and/or methods of achieving them. International Journal of Project Management, 11(2), 99-102. doi: 10.1016/0263-7863(93)90017-h

Turner, R. \& Ledwith, A. (2009) Project management in small to medium-sized enterprises. International Journal of Managing Projects in Business, 2(2), 282-296. doi:10.1108/17538370910949301.

Unger, B. N. et al. (2012). The three roles of a project portfolio management office: their impact on portfolio management execution and success. International Journal of Project Management, 30(5), 608-620. doi: 10.1016/j.ijproman.2012.01.015

Vandersluis, C. (2017). The project management system maturity model: white paper. Retrieved in December 3, 2016, from https://support.office.com/en-us/article/The-projectmanagement-system-maturity-model-white-paper77b7634e-97cc-4436-b1dd-1b8028f7c2eb

Vidal, L. A., Marle, F. \& Bocquet, J. C. (2011). Measuring project complexity using the analytic hierarchy process. International Journal of Project Management, 29(6), 718-727. doi. 10.1016/j.ijproman.2010.07.005

Voivedich, B. \& Jones, M. (2001). Developing and applying a project management capability maturity model. Paper presented at PMI Annual Seminars \& Symposium 2001, Nashville, Tennessee, USA.

Wendler, R. (2012). The maturity of maturity model research: A systematic mapping study. Information and Software Technology, 54, 1317-1339. doi. 10.1016/j.infsof.2012.07.007

Westerveld, E. (2002). The Project Excellence Model®: linking success criteria and critical success factors. International Journal of Project Management, 21(6), 411-418. doi: 10.1016/s02637863(02)00112-6

Yang, G. \& Qiu, W. (2010). The project management maturity model dynamic development research. Beihang University Transaction, 5(23), 4952.

Youker, R. (2017). The difference between different types of projects. $2^{\text {nd }}$ edition. PM World Journal, 6(4), 1-8.

Zandhuis, A. \& Stellingwerf, R. (2013). ISO 21500: Guidance on project management - a pocket guide. Zaltbommel: Van Haren Publishing. 


\section{Annex A}

\section{Application of PM2TOM2 using the example of Company $\mathbf{C}$}

When evaluating project management maturity of a company, in this case that of Company $\mathrm{C}$, we proceeded in the following steps:

\section{Collection of data in the organization carrying out the projects}

On the basis of the structured interviews with business representatives, it is necessary to identify the predominant type of projects carried out in the company. In the case of Company $\mathrm{C}$, it was large projects. Subsequently, it is necessary to identify the methods and tools of project management used in each stage of the project life cycle, taking into account the methods and tools assessed within PM2TOM2.

2. Analysis of the data obtained using the model designed

Based on the data found, it is necessary to award point scores to the individual PM2TOM2 criteria, while respecting the following procedure.

In the area time management, the first rated criterion is Gantt Chart. It is assessed whether the Gantt Chart is used, specifically at those stages of the project life cycle in which it is well-founded. On the basis of the information obtained, the point score is then established with respect to the project life cycle stages in which the method is used by the company. Company $\mathrm{C}$ makes use of Gantt Chart in the planning, implementation and evaluation stages. Thus, Company $\mathrm{C}$ was awarded 4 points for the use in the planning stage, 1 point for the use in the implementation stage and 1 point for the use in the evaluation stage, i.e. it was awarded the total of 6 points. The total number of points is then multiplied by the corresponding PM2TOM2 coefficient determined with respect to the prevailing type of projects carried out. Large projects are predominant in Company $\mathrm{C}$, the total number of points was thus multiplied by 1 and the resulting score is 6 .

The second criterion assessed in this area is the use of CPM or MPM. It is assessed whether CPM or MPM are used, specifically at those stages of the project life cycle in which it is well-founded. Given the fact that it is not expedient to use both of these methods at the same time, one of them is considered to be sufficient. On the basis of the information obtained, the point score is then established with respect to the project life cycle stages in which the method is used by the company. Company $\mathrm{C}$ makes use of CPM in the planning, implementation and evaluation stages. Company $\mathrm{C}$ was thus awarded $6+1+1$ points in this criterion, i.e. the total of 8 points. The total number of points is then multiplied by the corresponding PM2TOM2 coefficient determined with respect to the prevailing type of projects carried out. Large projects are predominant in Company $\mathrm{C}$, the total number of points was thus multiplied by 1 and the resulting score is 8 .

The third criterion assessed in this area is the use of PERT or GERT. Their use is assessed at those stages of the project life cycle in which it is well-founded. Also in this case, however, it is not expedient to apply both methods at the same time, and the use of one of them is considered to be sufficient. The point score for using one of these methods is then established with respect to the project life cycle stages in which the method is used by the company. Subsequently, the PM2TOM2 coefficient is determined with respect to the prevailing type of projects carried out by the company and the resulting score is calculated. In the case of Company $\mathrm{C}$, it was found that it makes use of neither of these methods. Its resulting score for this criterion is thus 0 points. The fourth criterion assessed in this area is the use of the Critical Chain Method. Its use is assessed at those stages of the project life cycle in which it is wellfounded. On the basis of the information obtained, the point score is then established with respect to the project life cycle stages in which the method is used by the company. Company $\mathrm{C}$ makes use of the Critical Chain Method in the planning, implementation and evaluation stages. Company $\mathrm{C}$ was thus awarded $6+1+1$ points, i.e. the total of 8 points. The total number of points is then multiplied by the corresponding PM2TOM2 coefficient determined with respect to the prevailing type of projects carried out. Large projects are predominant in Company $\mathrm{C}$, the total number of points was thus multiplied by 1 and the resulting score is 8 .

The last criterion in the area of time management is the Monte Carlo Method. Its use is assessed at those stages of the project life cycle in which it is wellfounded, i.e. in the concept, planning and evaluation stages. On the basis of the information obtained, the point score is then established with respect to the project life cycle stages in which the method is used by the company. The total number of points is then multiplied by the corresponding PM2TOM2 coefficient determined with respect to the prevailing type of projects carried out. In the case of Company $\mathrm{C}$, it was found that this method is not used in the company. Its final score for this criterion is thus 0 points.

Subsequently, the total number of points for the respective area is determined. In the case of Company $\mathrm{C}$, it is 22 points $(6+8+0+8+0)$ for time management. An analogous procedure is used with each criterion in other areas, i.e. areas of resource management, cost management, risk management and scope management.

In the area of organizational support to the projects and staff training, the criteria staff education in project management, the use of outside advisors and 
project managers, Organizational Standards to Support Project Management and PMO are assessed analogically as with the above criteria. The assessment of the applied organizational structure is then performed in a different way when points are only awarded for one currently used form. This criterion implies an impact on all stages of the project life cycle. If the company manages projects within organizational units, it is awarded 4 points; if the company has a matrix organizational structure, it is awarded 6 points; if the company has a project organizational structure, it is awarded 8 points. As Company $\mathrm{C}$ implements a project organizational structure, it was this awarded 8 points. The total number of points is then multiplied by the corresponding PM2TOM2 coefficient determined with respect to the prevailing type of projects carried out. In the case of Company $\mathrm{C}$ carrying out mainly large projects, the coefficient was 1 . Its final score for the organizational structure is 8 points. In the case of Company $\mathrm{C}$, the total number of points for the organizational support for projects and staff training is $31(8+7+8+8+0)$.

The last assessed area is project management software support. In this case, similarly to the assessment of the organizational structure used, points are awarded for one particular form of Based on the final score in individual areas, it is possible to draw conclusions as to in which areas the project management methods and tools are used in a company to a limited extent, where they are used inadequately in terms of the individual stages of the project life cycle and, as the case may be, where they are used inappropriately with respect to the type of software support application used. In Company C, the Enterprise Resource Planning System is used. This system is linked to a specialized project management application with the wide range of functionality. Company $\mathrm{C}$ uses it in all stages of the project life cycle. Company $\mathrm{C}$ was thus awarded 8 points $(2+2+2+2)$. The total number of points is then multiplied by the corresponding PM2TOM2 coefficient determined with respect to the prevailing type of projects carried out. In the case of Company $\mathrm{C}$ carrying out predominantly large projects, the coefficient was 1 . Its final score for the project management software support is then 8 points.

Subsequently, the total score for all the areas assessed is to be determined for each company. In the case of Company $\mathrm{C}$, the total score was 164 $(22+18+24+24+37+31+8)$.

3. Evaluation of project management maturity The final score for all areas is compared with the proposed range of points for individual project management maturity levels (see Table 2). The achieved project management maturity level of Company C was determined as Advanced Management Maturity Level.

4. Use of the evaluation results prevailing projects. This assessment can then be used in designing changes in practice. In the case of Company $\mathrm{C}$, the results were presented to the representatives of the company, who, on the basis thereof, considered the adoption of adequate changes. 